\title{
Characterization of Plant Growth-Promoting Rhizobacteria Isolated from Chilli Rhizosphere of Southern Plateau and Hills Region
}

\author{
Abhijeet Shankar Kashyap ${ }^{1,2}$, DineshSingh ${ }^{1 *}$, \\ Amit Kumar Kesharwani ${ }^{1}$ and Ravinder Pal Singh ${ }^{1}$ \\ ${ }^{1}$ Division of Plant Pathology, Indian Agricultural Research Institute, Delhi, India \\ ${ }^{2}$ Plant Pathology lab, ICAR-National Bureau of Agriculturally Important Microorganisms, \\ Maunath Bhanjan-275103, India \\ *Corresponding author
}

\section{A B S T R A C T}

Keywords

PGPR, Antagonist,

Chilli and

rhizobacteria

\section{Article Info}

Accepted:

26 July 2020

Available Online:

10 August 2020
Plant Growth Promoting Rhizobacteria (PGPR) is a community of bacteria located in the rhizosphere of plant which are can suppress directly or indirectly plant diseases caused by different plant pathogens and also promote plant growth. Twenty three rhizospheric soil samples of chilli plants from Southern Plateau and Hills region agro-climatic zones of Karnataka and Andhra Pradesh states of India) were collected and isolated on four different types of media viz. TSA (Tryptone soya agar), NA (Nutrient Agar), CPG (Casamino peptone glucose) and Kings' B media in the present study. A total of thirty one bacterial isolates were isolated and screened their antagonistic against Ralastonia solanacearum UTT- 25 and plant growth promoting activities in vitro condition. Out of 31 isolates of rhizobacteria, $35.4 \%$ rhizobacteria showed antagonistic ability to inhibit growth of $R$. solanacearum. In vitro screening of PGP activities rhizobacteria showed phosphate solubilization $(64.2 \%)$, production of IAA $(78.5 \%)$, production of ammonia (78.5\%), production of $\mathrm{HCN}(35.7 \%)$, and siderophore production $(50 \%)$. The rhizobacterial isolates showing plant growth promoting activities along with having biocontrol potentials were characterized using morphological, biochemical and physiological. These rhizobacteria are good potential to use as biopesticide and biofertilizers for improving crop health and growth.

\section{Introduction}

One of the most important commercial crops grown in India is chilli (Capsicum annuum L.). It is a tropical and subtropical crop, needing a warm humid climate and is an important condiment of Indian cuisine due to its pungence, colour, aroma and flavour. It is used in one form or the other for daily diet.
India is the largest producer of chilies in the world, accounting for about 50 percent of production and about 20 percent of production exports (National Horticulture Board, 2018-19). Chili is grown in India over an area of 0.654 million hectares with a output of 1.039 million tonnes, with a productivity of $1588 \mathrm{~kg} / \mathrm{ha}$ (FAO 2018). India accounts for an annual production of 
approximately 1.1 million, followed by China (around 0.4 million tonnes), Mexico and Pakistan (around 0.3 million tonnes). The most important chilli states in India are Telangana (32.76\%), Karnataka (25.01\%) and Madhya Pradesh (23.51\%) (National Horticulture Board, 2018-19).Chilli is known to be affected by as many as 83 various diseases, but major 26 diseases, among them 2 are serious disease which is caused by bacteria (Rangaswami, 1988). Between numerous diseases caused by fungi, bacteria and viruses, the bacterial wilt caused by Ralstonia solanacearum (Wicker et al., 2007, Singh 2014) are considered to be one of the major important diseases causing losses of up to $90 \%$. The disease is prevalent in Karnataka, Kerala, Maharashtra, Orissa and West Bengal in India causing heavy yield losses.

The worldwide use of pesticides rose by $4.4 \%$ annually in the 2000's (Zhang et al., 2018). Every year, 2 million tons of active ingredient pesticides and fungicides are used worldwide, leading, of course, to further pollution. However, increased use of chemical inputs has led to many negative effects, i.e. a decline in soil biodiversity of soil microorganism; harmful effects on aquatic environments of pesticide runoff, disease resistance formed and adverse environmental impacts (Urban and Lebeda, 2004; $\mathrm{Ma}$ and Michailides, 2005).

Rising major safety issues, environmental risks and stringent legislation and limitations on the use of dangerous chemicals have led to a growing market for new, safer approaches to manage plant diseases. Biological control using microbes like rhizobia is an alternative method for management of the disease (PGPRs) (Kashyap et al., 2017; Ranjan et al., 2015; Singh et al., 2012). Rhizobacteria act as an antagonistic agent to reduce disease incidence and overall improve crop health. Therefore, to satisfy the growing demand for chemical residue-free agricultural products, there is a need to look for more effective and efficient biocontrol agents. The population dynamics of the pathogen in rhizobacteriatreated chilli should be investigated, since they have proved to be resistance-inducing agents in host plants. The study will be helpful to find most potential antagonistic rhizobacteria having plant growth promoting ability. The present study was undertaken to find out potential rhizobacteria from rhizosphere of chilli plants from Southern Plateau and Hills region to have antagonistic and plant growth promoting activities under in vitro conditions and their characterizations using advanced molecular techniques.

\section{Materials and Methods}

\section{Sample collection and isolation of rhizobacteria}

The rhizospheric soil of chilli was collected from different agro-climatic regions of India such as Guntur, Warangal (Andhra Pradesh), Raichur, Gulbarga, Dharwad, Chintamani and Bangaluru (Karnataka) under southern plateau and hills. The rhizobacterial strains used in this study were isolated by serial dilution method on different growth medium such as TSA (Tryptone soya agar), NA (Nutrient Agar), CPG (Casamino peptone glucose) and Kings' B media at $28 \pm 1^{\circ} \mathrm{C}$ for 48 72h(Schaad et al., 2001; Tan et al., 2013).

The isolated bacteria showing irregular and creamy white morphology were maintained on YGCA (yeast glucose carbonate agar) medium. These cultures were store at $4^{\circ} \mathrm{C}$ further use.

\section{Characterization of antagonism of rhizobacteria against $R$. solanacearum}

The antagonistic properties of 31 rhizobacterial isolates of chilli against $R$. Solanacearum (UTT25) were screened by dual culture method (Singh et al., 2014). 


\section{Characterization of rhizobacteria for plant growth promoting traits}

\section{Phosphorus solubilization}

Rapid screening of phosphate solubilization by rhizobacteria was performed on picovskaya media. $48 \mathrm{~h}$ old culture of the most potentially best antagonistic isolates from rhizobacterial isolates was inoculated in the picovskaya (PVK) broth medium and incubated at $280 \mathrm{C}$ for 3-5 days. Then $1 \mathrm{ml}$ of each culture was taken separately in the culture tube and $10 \mathrm{ml}$ of ammonium molybdate was added to each bacterial culture and mixed thoroughly. The blue color intensity of the solution was measured by UV-VIS Spectrophotometer (Hitachi, U2900) of $600 \mathrm{~nm}$ and the corresponding amount of soluble phosphorous was determined by the standard curve (Mehta and Nautiyal 2001).

\section{Indole acetic acid (IAA) production}

The production of IAA was estimated in accordance with the procedure (Vikram et al., 2007). Twenty five $\mathrm{ml}$ of the supernatant of rhizobacteria were collected and the $\mathrm{pH}$ was adjusted to 2.8 with $1 \mathrm{~N} \mathrm{HCL}$ in a $100 \mathrm{~mL}$ conical flask. Equal volume of diethyl ether was added and incubated in the dark for $4 \mathrm{~h}$. Indole acetic acid extraction was performed at $4^{\circ} \mathrm{C}$ in a separate funnel using diethyl ether.

The organic phase was discarded and the solvent was pooled and the IAA in the methanol extract was determined. To $0.5 \mathrm{~mL}$ of methanol extract, $1.5 \mathrm{~mL}$ of double distilled water and $4 \mathrm{~mL}$ of Sapler reagent (1 $\mathrm{mL}$ of $0.5 \mathrm{M} \mathrm{FeCl}_{3}$ in $50 \mathrm{~mL}$ of $35 \%$ perchloric acid) were added and incubated in the dark for $1 \mathrm{~h}$. The intensity of the pink color developed was read in a spectrophotometer at $535 \mathrm{~nm}$.

\section{Siderophore production}

Siderophore production of rhizobacterial isolates was used as described by Singh et al., 2012. Production of Siderophore was tested on Petri dishes containing CAS-agar. $48 \mathrm{~h}$ old cultures of rhizobacterial isolates were stabbed on CAS-agar plates using sterile toothpicks and incubated at $28^{\circ} \mathrm{C}$ for two weeks in the dark. Colonies with orange zones were considered to be siderophore strains. Control plates of CAS-agar (uninoculated) were incubated under the same conditions and no color change in CAS-blue agar was observed after an incubation period of 1-14 days.

\section{Ammonia production}

Rhizobacterial isolates containing peptone water were inoculated; the tube was incubated at $30^{\circ} \mathrm{C}$ for 4 days. Then $1 \mathrm{ml}$ of Nessler's reagent was added to each tube. The presence of a faint yellow colour indicates a small amount of ammonia and a deep yellow to brownish color indicates the maximum production of ammonia.

\section{HCN production}

All isolated rhizobacteria were screened for hydrogen cyanide production following the method described by Bakker et al., (1987). Each rhizobacterium was streaked on nutrient agar medium added with glycine $(4.4 \mathrm{~g} / \mathrm{L})$. The agar was covered with a Whatman number 1 filter paper previously soaked in a specific solution $(0.5 \%$ picric acid and $2 \%$ sodium carbonate w/v).

The dishes were sealed with Parafilm and incubated at $28{ }^{\circ} \mathrm{C}$ for $48 \mathrm{~h}$. A change of colour of the filter paper from yellow to light brown, brown or reddish-brown was recorded as weak $(+)$, moderate $(++)$ or strong $(+++)$ reaction respectively. 


\section{Morphological and biochemical characterization}

Colony morphology, size, color, shape and growth pattern of 31 rhizobateria isolates were recorded after $24 \mathrm{~h}$ of growth on LB agar plates at $28 \pm 1{ }^{\circ} \mathrm{C}$ (Somasegaran and Hoben, 1994). Cell size and motility was observed by light microscopy. These isolates were biochemically characterized using various tests such as gelatin liquefaction, starch hydrolysis, $\mathrm{H}_{2} \mathrm{~S}$, Arginine, citrate, $\mathrm{KOH}$, Oxidase, arginine hydrolase, nitrate reduction and fermentation of various sugars as described by Schaad et al., (2001).

\section{Results and Discussion}

Chili rhizosphere soil samples were collected from agro-climatic regions of Southern Plateau and Hills. Rhizobacterial colonies have been isolated on various microbiological media, Nutrient agar, Kings B, Tryptone soya agar and casamino peptone glucose media. Various bacterial colonies were observed in the respective media. Thirty one rhizobacterial isolates were isolated from different rhizospheric soil of chilli and out of these, 17 isolates of rhizobacteria from Karnataka, 14 isolates from Andhra Pradesh were selected and screened for their various morphological characteristics of colonies on the media such as texture, size, margin, shape and pigmentation (Table 1). All the microbes identified have a smooth-rough-slim texture and a color range between pure whitetranslucent-light brown-red-cream-yellow (Fig. 1). Rhizobacteria were characterized by using morphological and biochemical methods (Table 2). Out of 31 rhizobacteria isolates, 14 rhizobacteria were characterized, in which 11 isolates showed $\mathrm{KOH}$ test negative and gram reaction positive. Majority of the isolates showed rod shaped (9 isolates) and five isolates were coccus shaped. All rhizobacteria showed positive for utilization glucose as carbon source and $42.86 \%$ isolates used galactose, and mannose as carbon sources. Xylose and sucrose were utilized by $78.57 \%$ rhizobacteria. In biochemical test, all isolates showed positive in catalase test, where as $92.86 \%$ isolates were positive in catalase test. Citrate utilization and $\mathrm{H}_{2} \mathrm{~S}$ production were recorded 64.29 and $50.00 \%$ isolates of rhizobacteria respectively, while 85.71 percent of rhizobacteria were positive for amylase production. It indicates that there are diverse group of bacteria present in the rhizosphere of chilli plants and they behave differently in utilization of carbon sources and production of different enzymes. As reported earlier that rhizospheric soil of chilli plant has a plenty of bacterial populations including antagonistic, plant growth stimulating bacteria and other bacteria. In these bacterial population, majority of them belong to Bacillus species and Bacillus derived genera isolated especially from the rhizospheric soil of wheat (Upadhyay et al., 2009) and tomato (Tan et al., 2013 Singh et al., 2016) plants.

In Antagonistic assay, out of 31 isolates of rhizobacteria, 11 isolates showed positive result to inhibit the growth of Ralstonia solanacearumin vitro conditions. The presence of rhizobacterial isolates, isolate KA9 isolated from Karnataka formed highest inhibition zone (20.6 mm diameter) against $R$. solanacearum after $48 \mathrm{~h}$.

The inhibition zone formed by rhizobacteria was increased significantly by increasing the duration of culturing from $48 \mathrm{~h}$ to $144 \mathrm{~h}$ in broth culture (Fig. 2a and 2b). However, out 31 isolates, $64.52 \%$ isolates did not show inhibitory effect on the growth of $R$. solanacearum in vitro conditions (Table 3 ). 
Table.1 Morphological characterization of rhizobacterial colonies on isolates from rhizospheric soil of chilli from Karnataka and Andhra Pradesh states of India

\begin{tabular}{|c|c|c|c|c|c|c|c|}
\hline Isolates & Size & Shape & Margin & Opacity & Elevation & Texture & Pigmentation \\
\hline KA-1 & Small & Irregular & Entire round & Opaque & Convex & Smooth & Light yellow \\
\hline KA-2 & Large & Round & Entire round & Opaque & Concave & Smooth & $\begin{array}{l}\text { Creamy- } \\
\text { white }\end{array}$ \\
\hline KA-3 & Medium & Round & Entire round & Transparent & Flat & Smooth & Nil \\
\hline KA-4 & Large & Regular & Entire round & Opaque & Convex & Smooth & $\begin{array}{c}\text { Greenish } \\
\text { yellow }\end{array}$ \\
\hline KA-5 & Medium & Round & thick ridges & Opaque & Convex & smooth, moist & Gray-white \\
\hline КА-6 & Large & Uniform & Undulate & Opaque & Flat & Rough & White \\
\hline KA-7 & Large & Regular & Entire round & Opaque & Convex & Smooth & $\begin{array}{l}\text { Greenish } \\
\text { yellow }\end{array}$ \\
\hline KA-8 & Small & Regular & Entire round & Opaque & Convex & Smooth & Light red \\
\hline KA-9 & Small & Irregular & Entire round & Opaque & Convex & Smooth & Light yellow \\
\hline KA-10 & Large & Round & Undulate & Semi- transparent & Flat & $\begin{array}{l}\text { Slummy } \\
\text { rough }\end{array}$ & Off-white \\
\hline KA-11 & Large & Irregular & Undulate & Opaque & Flat & Smooth & $\begin{array}{c}\text { Greenish } \\
\text { yellow }\end{array}$ \\
\hline KA-12 & Small & Round & Entire round & Opaque & Convex & Smooth & White \\
\hline KA-13 & Large & Irregular & Entire round & Opaque & Flat & Smooth & Pale yellow \\
\hline KA-14 & Small & Uniform & Entire round & Transparent & Convex & $\begin{array}{l}\text { Smooth- } \\
\text { slums }\end{array}$ & Nil \\
\hline KA-15 & Medium & Uniform & Entire round & Semi- transparent & Flat & Smooth & Light brown \\
\hline KA-16 & Very small & Uniform & Entire round & Opaque & Flat & Smooth & $\begin{array}{c}\text { Greenish } \\
\text { yellow }\end{array}$ \\
\hline KA-17 & Medium & Irregular & Undulate & Opaque & Flat & Irregular & White \\
\hline AP-1 & Medium & Uniform & Entire round & Opaque & Flat & $\begin{array}{l}\text { Smooth- } \\
\text { shiny }\end{array}$ & Off-white \\
\hline AP-2 & Large & Uniform & Entire round & Semi- transparent & Flat & $\begin{array}{l}\text { Smooth- } \\
\text { shiny }\end{array}$ & Nil \\
\hline AP-3 & Medium & Round & Entire round & Transparent & Flat & Smooth & Nil \\
\hline AP-4 & Medium & Round & thick ridges & Opaque & Convex & smooth, moist & Gray-white \\
\hline AP-5 & Very small & Uniform & Entire round & Opaque & Flat & Smooth & White \\
\hline AP-6 & Medium & Round & Entire round & Transparent & Flat & Smooth & Nil \\
\hline AP-7 & Small & Uniform & Entire round & Transparent & Convex & $\begin{array}{l}\text { Smooth- } \\
\text { slums }\end{array}$ & Nil \\
\hline AP-8 & Large & Regular & Entire round & Opaque & Convex & Smooth & Off white \\
\hline AP-9 & Large & Round & Entire round & Opaque & Convex & Smooth & Off white \\
\hline AP-10 & Small & Uniform & Entire round & Opaque & Convex & $\begin{array}{l}\text { Smooth, } \\
\text { Shiny }\end{array}$ & $\begin{array}{l}\text { Greenish } \\
\text { yellow }\end{array}$ \\
\hline AP-11 & Large & Regular & Entire round & Opaque & Convex & Smooth & Off white \\
\hline AP-12 & Small & Round & Entire round & Opaque & Convex & Smooth & White \\
\hline AP-13 & Very small & Uniform & Entire round & Opaque & Flat & Smooth & White \\
\hline AP-14 & Small & Uniform & Entire round & Transparent & Convex & $\begin{array}{l}\text { Smooth- } \\
\text { slums }\end{array}$ & Nil \\
\hline
\end{tabular}


Table.2 Morphological and biochemical characterization of rhizobacteria isolates isolated from rhizosphere of chilli from Karnataka and Andhra Pradesh states of India

\begin{tabular}{|c|c|c|c|c|c|c|c|c|c|c|c|c|c|c|c|}
\hline Strains & $\begin{array}{l}\vec{v} \\
\vec{v} \\
0 \\
0\end{array}$ & שี & 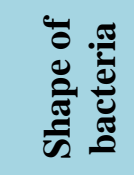 & 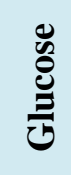 & 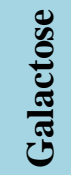 & 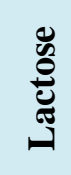 & & 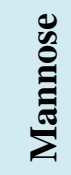 & $\frac{\ddot{D}}{\grave{2}}$ & 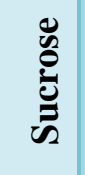 & 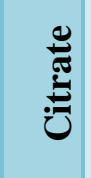 & $\underset{\mathbb{N}}{\boldsymbol{N}}$ & 蒫 & 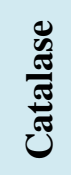 & $\frac{\grave{z}}{\grave{z}}$ \\
\hline KA2 & - & + & Cocci & \pm & - & - & - & \pm & \pm & \pm & - & + & + & + & + \\
\hline KA3 & - & + & Cocci & + & + & + & - & - & + & + & + & + & + & + & + \\
\hline KA5 & - & + & Rod & \pm & - & - & + & + & \pm & + & + & - & + & + & + \\
\hline KA-7 & + & - & Rod & + & + & - & + & + & - & + & + & - & + & + & + \\
\hline KA9 & - & + & Rod & + & - & - & - & + & + & + & + & - & + & + & + \\
\hline KA13 & - & + & Rod & + & + & - & + & - & + & - & + & + & + & + & + \\
\hline KA14 & - & + & Rod & + & + & + & - & - & + & + & + & - & + & + & + \\
\hline KA-15 & + & - & Rod & + & - & + & + & - & + & - & - & + & - & + & + \\
\hline KA-17 & + & - & Rod & + & + & - & + & - & + & + & - & - & + & + & + \\
\hline AP8 & - & + & Rod & + & - & - & + & + & - & - & - & + & + & + & - \\
\hline AP13 & - & + & cocci & + & - & + & + & - & + & + & + & + & + & + & - \\
\hline AP2 & - & + & cocci & + & + & - & + & + & - & + & + & - & + & + & + \\
\hline AP6 & - & + & cocci & + & - & + & - & - & + & + & - & - & + & + & + \\
\hline AP11 & - & + & Rod & \pm & - & - & \pm & - & + & + & + & + & + & + & + \\
\hline
\end{tabular}

Table.3 Characterization of selected isolates of rhizobacteria for their plant growth promoting traits isolated from Southern Plateau and Hills region of India

\begin{tabular}{|l|c|c|c|c|c|}
\hline $\begin{array}{l}\text { Isolates of } \\
\text { rhizobacteria }\end{array}$ & $\begin{array}{c}\text { IAA } \\
\text { Production }\end{array}$ & $\begin{array}{c}\text { Phosphorus } \\
\text { solubilization }\end{array}$ & $\begin{array}{c}\text { Ammonia } \\
\text { production }\end{array}$ & $\begin{array}{c}\text { HCN } \\
\text { Production }\end{array}$ & $\begin{array}{c}\text { Siderophores } \\
\text { Production }\end{array}$ \\
\hline KA2 & + & + & ++ & + & + \\
\hline KA3 & + & + & + & - & - \\
\hline KA5 & - & + & + & + & + \\
\hline KA-7 & + & - & + & - & - \\
\hline KA9 & +++ & + & ++ & + & + \\
\hline KA13 & + & - & - & - & - \\
\hline KA14 & + & + & + & - & + \\
\hline KA-15 & - & + & - & + & + \\
\hline KA-17 & + & - & + & - & - \\
\hline AP8 & + & + & + & - & + \\
\hline AP13 & ++ & + & + & + & - \\
\hline AP2 & - & - & + & - & + \\
\hline AP6 & + & + & + & - & - \\
\hline AP11 & + & + & - & + & - \\
\hline
\end{tabular}


Fig.1 Representative photographs of rhizobacterial colonies on different media
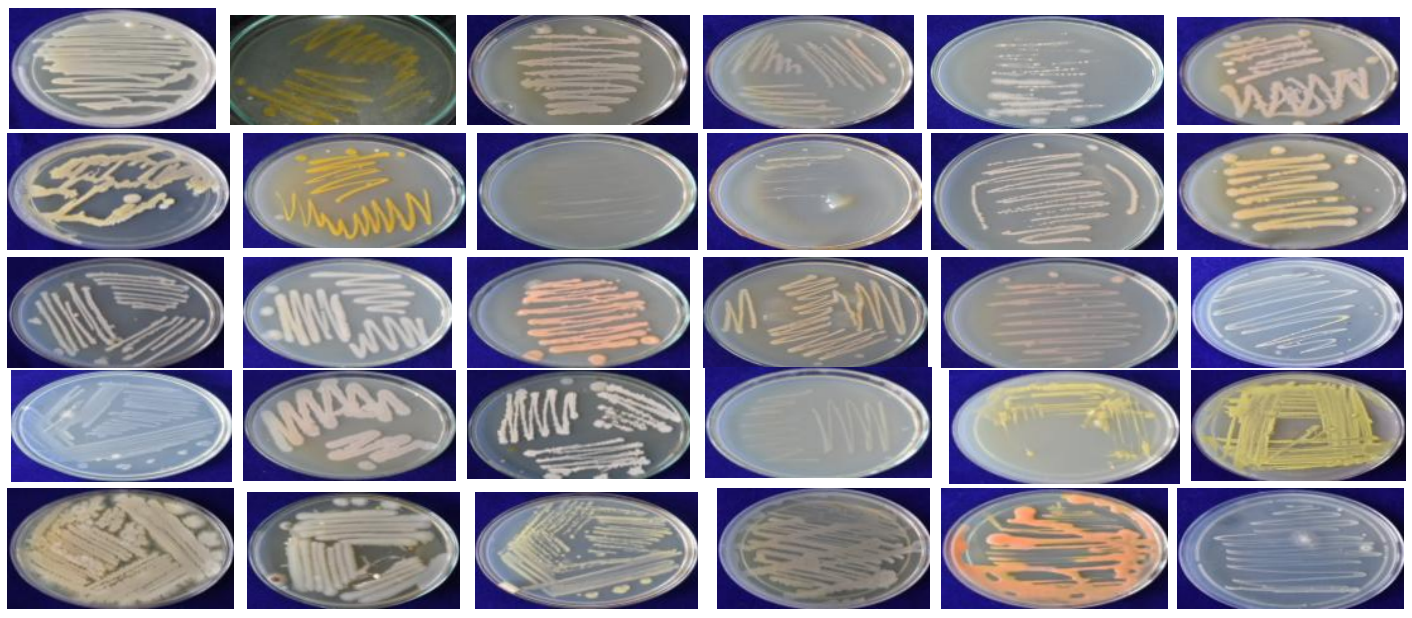

Fig.2a Showing antagonistic activity of rhizobacteria isolates against Ralstonia solanacearum under in vitro conditions

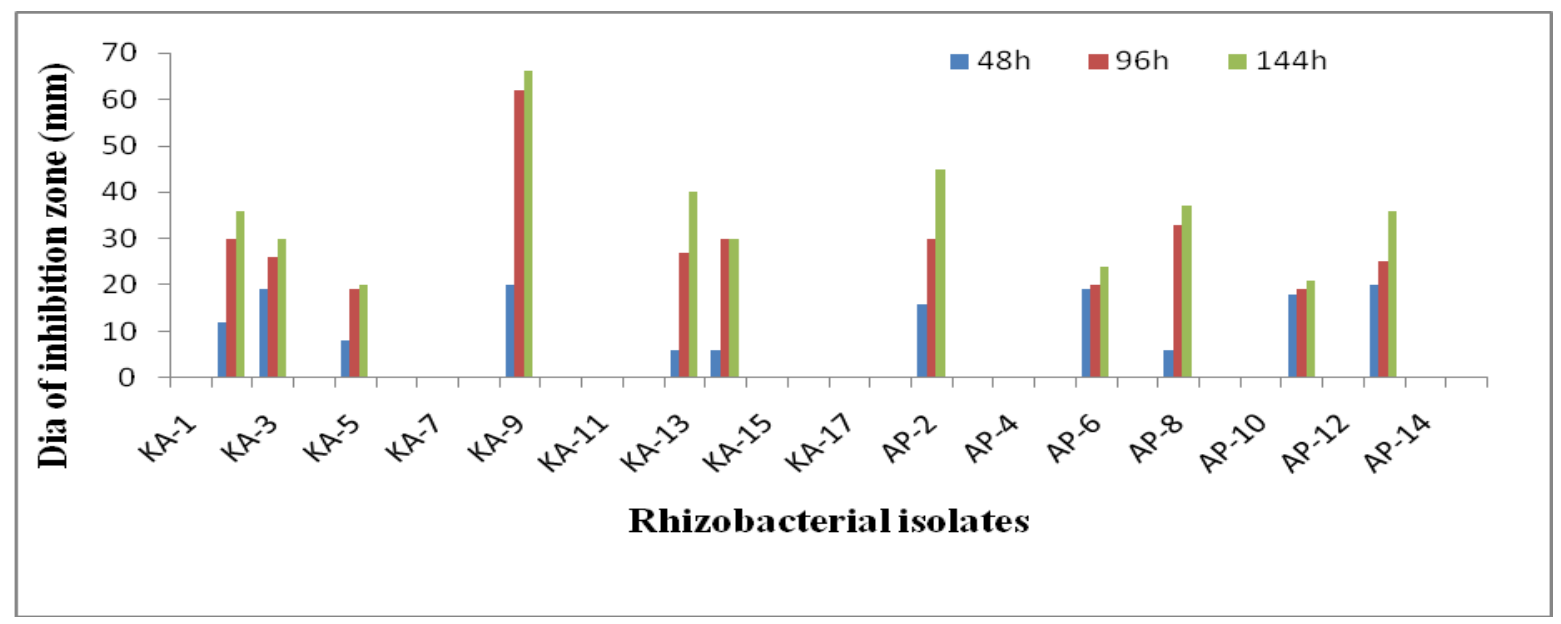

Fig.2b Antagonistic activity of rhizobacterial isolates against Ralstonia solanacearum under in vitro conditions

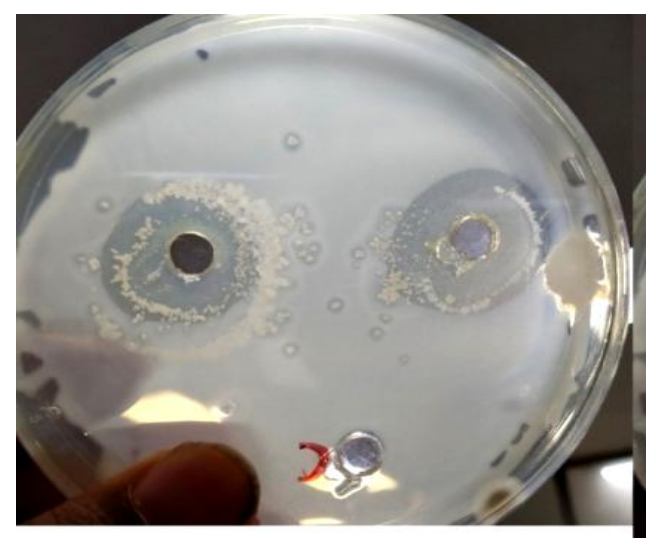


Fig.3 In vitro assay for plant growth promoting activities of rhizobacteria isolates isolated from rhizosphere of chilli

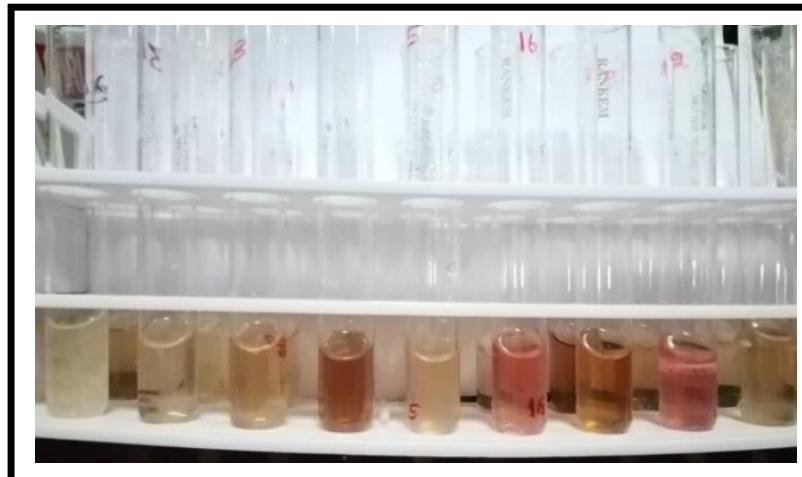

a) IAA production

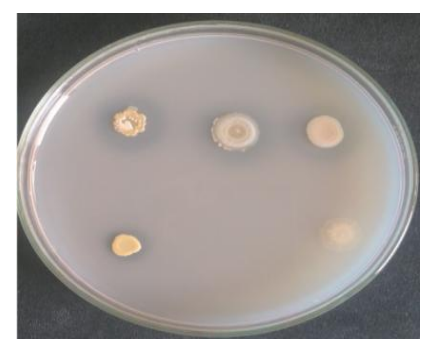

c) P-solubilization

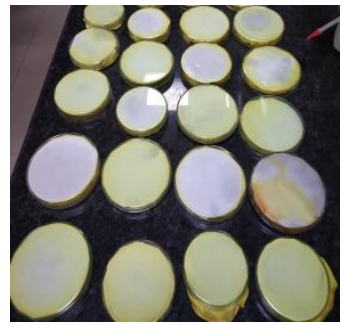

d) $\mathrm{HCN}$

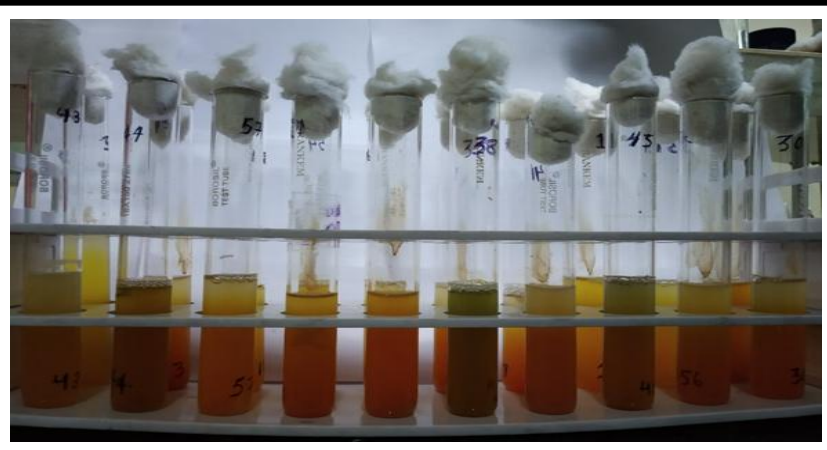

b) Ammonia production
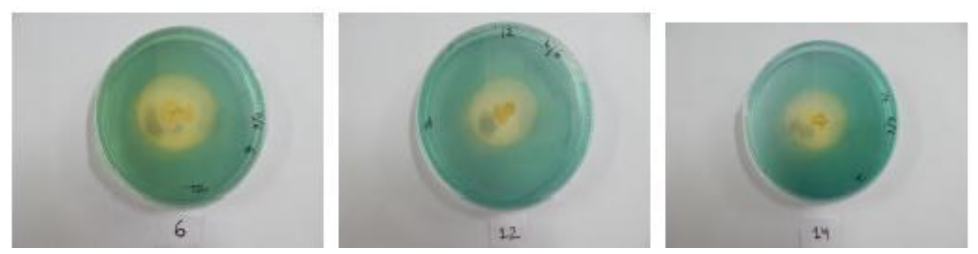

e) Siderophore production
The rhozbacteria inhibited the growth o $R$. solanacearum on agar medium might be due to the production of secondary metabolites by the rhizobacteria (Gross and Vidaver, 1990) particularly antibiotic production ( Aliya et al., 2008; Singh et al., 2013).

The eleven isolates of rhizobacteria having antagonist activity against $R$. solanacearum along with three more isolates those did not show antagonistic activity were selected for plant growth promoting such as production of indole acetic acid, siderophores, ammonia, Hydrogen cyanide and phosphate solubilization under in vitro conditions (Fig. 3 ). Table 2 reveals that out of 14 rhizobacteria isolates $78.57 \%$ isolates showed positive in production of indole acetic acid and among them, isolate KA9 showed most potential for production of indole acetic acid followed by isolate AP13. Similar finding has also been reported in B. amyloliquefaciens FZB42, which produces IAA to promote the plant growth (Idris et al., 2007), which is an important growth promoting hormones for the plant. $71.43 \%$ isolates were able to solubilize phosphorus and $78.57 \%$ isolates produced ammonia in vitro conditions. The phosphorus was solubilised by $>70 \%$ isolates of rhizobacteria which is an important major nutrient element for plant. Fifty percent isolates were able to produced siderophores while only $42.86 \%$ isolates produced hydrogen cyanide. Siderophores, which may contribute as iron chelating and produces soluble complexes which is taken by plant or it make insoluble to phytopathogenic bacteria by binding the available form of iron in the soil (Kamnev and van der Lelie, 2000). Among these isolates, KA9 and KA2 isolates had ability to produce all pant growth promoting traits like production of indole 
acetic acid, siderophores, ammonia, Hydrogen cyanide and phosphate solubilization (Fig 4, Table 2). The results indicate that all rhizobacteria did not possess ability to promote plant growth. Isolation of potential antagonistic bacteria from the soil is an important way to control plant disease successfully (Kohl et al., 2015). However, This shows that KA9 KA2 and AP13isolates have a potential for plant growth promotions and in most studies it has been found that PGPR promotes the emergence of seedlings, crop yield, plant growth and plant protection against phytopathogens (Dey et al., 2004; Herman et al., 2008; Kloepper et al., 2004; Kokalis et al., 2006).

Based on morphological, Biochemical and PGP traits screening, we found three rhizobacteria isolates KA9, KA2 and AP13 showing most promising results in terms of biocontrol potential and plant growth promotions. Plant growth promoting (PGP) traits, morphological, and biochemical were done and found variable characteristic results in our studies. This type of research is important because it promotes the use of PGPR as biofertilizers or as bioinoculants as an effective approach to reducing the use of harmful pesticides and chemical fertilizers.

\section{Acknowledgement}

The authors wish to express their sincere thanks to the to the Head and professor, Division of Plant Pathology, Indian Agricultural Research Institute, New Delhi India, for providing laboratory facilities. The authors extend their gratitude to the Indian Council of Agricultural Research, New Delhi; Director, ICAR-National Bureau of Agriculturally Important Microorganisms, Maunath Bhanjan, U.P India for providing financial assistance during the course of the study.

\section{References}

Aliye N, Chemeda F, Yaynu K (2008) Evaluation of rhizosphere bacteria antagonists for their potential to bioprotect potato (Solanum tuberosum) against bacterial wilt (Ralstonia solanacearum). Bio Control 47: 282288.

Bakker P. A. H. M., Bakker A. W. Marugg J. D., Weisbeek P. J. and Schippers B. (1987) Bioassay for studying the role of siderophores in potato growth stimulation by Pseudomonas spp. in short potato rotations. Soil Biolog \& Biochernhtrj, 19, U3449.

Compant S, Duffy B, Nowak J, Cle'ment C, EA BI (2005) Use of plant growthpromoting bacteria for biocontrol of plant diseases: principles, mechanisms of action, and future prospects. Appl Environ Microbiol 71:4951-4959

Dey R, Pal K. K, Bhatt D. M, Chauhan S. M (2004) Growth promotion and yield enhancement of peanut (Arachis hypogaea L.) by application of plant growth promoting rhizobacteria. Microbiol. Res. 159:371-394

(Food and agriculture) http://www.fao.org/news/archive/news-

Gross, D.C. and Vidaver, A.K. 1990 Bacteriocins. In: Methods in Phytobacteriology (eds Z. Klement K. Rudolph \& D.C Sands), pp. 245249.

Herman, M A B, Nault B A and Smart C D. (2008). Effects of plant growth promoting rhizobacteria on bell pepper production and green peach aphid infestations in New York. Crop Protect. 27:996-1002.

Idris EE, Iglesias DJ, Talon M, Borriss R (2007). Tryptophan-dependent production of indole-3-acetic acid (IAA) affects level of plant growth promotion by Bacillus amyloliquefaciens FZB42. Mol Plant 
Microbe Interact 20: 619-626.

Kamnev AA, van der Lelie D (2000) Chemical and biological parameters as tools to evaluate and improve heavy metal phytoremediation. Biosci Rep 20: 239-258.

Kashyap A S, Pandey V K, Manzar N, Kannojia P, Singh U B and Sharma P K (2017), Role of plant growth-promoting rhizobacteria for improving crop productivity in sustainable agriculture D. Singh, H. Singh, R. Prabha (Eds.), Plant-Microbe Interactions in AgroEcological Perspectives, Springer, Singapore 673-693

Kloepper, J W, Ryu C M, and Zhang S. (2004) Induced systemic resistance and promotion of plant growth by Bacillus spp. Phytopath.94:1259-1266.

Köhl J, Postma J, Nicot P, Ruocco M, Blum B (2011) Stepwise screening of microorganisms for commercial use in biological control of plant-pathogenic fungi and bacteria. Biological Control 57: 1-12.

Kokalis-Burelle N, Kloepper J W, and Reddy M S. (2006) Plant growth-promoting rhizobacteria as transplant amendments and their effects on indigenous rhizosphere microorganisms. Appl. Soil Ecol. 31:91-100.

Ma Z., Michailides T.J. (2005) Advances in understanding molecular mechanisms of fungicide resistance and molecular detection of resistant genotypes in phytopathogenic fungi. Crop Protection, 24, 853-863.

Mehta, S. and Nautiyal, C.S. (2001) An efficient method for qualitative screening of phosphate solubilizing bacteria. Current Microbiology, 43, 5155.

http://nhb.gov.in/annual_report.aspx?enc $=3 Z$ OO8K5CzcdC/Yq6HcdIxOBX3ZfjXi13 RgCoILztD0k (National Horticulture Board)
Rangaswami G (1988) Diseases of crop plants in India. Print book. English.3rd ed.p124-125

Ranjan R. K, Singh D, Sharma P and Shridhar (2015) Characterization and genetic diversity of Ralstonia solanacearum causing brown rot disease of potato. Indian Phytopath. 68 (4): 368-374

Reyes V A, and Valduz Z. (2006). Phosphate solubilizing microorganisms isolated from the rhizospheric and bulk soils of colonizer plants at an abandoned rock phosphate mine. Plant Soil 287: 69-75.

Schaad NW, Jones JB, Chun W (2001) Laboratory guide for the identification of plant pathogenic bacteria. St Paul: American Phytopathological Society, (3rdedn): 373.

Singh D, Sinha S, Chaudhary G, Yadav D K and Mondal K K (2014) Genetic diversity of biovar 3 and 4 of Ralstonia solanacearum causing bacterial wilt of tomato using BOX- PCR, RAPD and hrp gene sequences. Indian Journal of Agricultural Sciences, 84(3): 391-5

Singh D, Yadav D K, Sinha S and Upadhyay BK (2012) Utilization of plant growth promoting Bacillus subtilis isolates for the management of bacterial wilt incidence in tomato caused by Ralstonia solanacearum race 1 biovar 3 . Indian Phytopath. 65 (1): 18-24

Singh D, Yadav DK, SinhaShweta, Mondal K K, Singh Gita, et al., (2013) Genetic diversity of iturin producing strains of Bacillus species antagonistic to Ralstonia solanacerarum causing bacterial wilt disease in tomato. African Journal of Microbiology Research 7: 5459-5470.

Singh D, Yadav DK, Chaudhary G, Rana VS, Sharma RK (2016) Potential of Bacillus amyloliquefaciens for Biocontrol of Bacterial Wilt of Tomato Incited by Ralstonia solanacearum. J Plant Pathol Microbiol 7: 327. doi:10.4172/2157- 
7471.1000327

Tan S, Jiyang Y, Song S, Huang J, Ling N, et al., (2013) Two Bacillus amyloliquefaciens strains isolated using the competitive tomato root enrichment method and their effects on suppressing Ralstonia solanacearum and promoting tomato plant growth. Crop Protection 43: $134-140$

Upadhyay SK, Singh DP, Saikia R (2009) Genetic diversity of plant growth promoting rhizobacteria isolated from rhizospheric soil of wheat under saline condition. Current Microbiology 59: 489-496.

Urban J. and Lebeda A. (2004) Resistance to fungicides in population of cucurbit downy mildew in the Czech Republic. Actafytotechnicaet zootechnic, 7, 327329.

Vikram A, Hamzehzarghani H, Alagawadi A $\mathrm{R}$, Krishnaraj P U, and Chandrashekar B S. (2007) Production of plant growth promoting substances by phosphate solubilizing bacteria isolated from vertisols. Journal of Plant Science.2: 326- 333.

Zhang W (2018) Global pesticide use: Profile, trend, cost / benefit and more. Proc. Int. Acad Ecol. and Environ. Sci., 2018, 8(1): 1-27.

\section{How to cite this article:}

Abhijeet Shankar Kashyap, DineshSingh, Amit Kumar Kesharwani and Ravinder Pal Singh. 2020. Characterization of Plant Growth-Promoting Rhizobacteria Isolated from Chilli Rhizosphere of Southern Plateau and Hills Region. Int.J.Curr.Microbiol.App.Sci. 9(08): 34733483. doi: https://doi.org/10.20546/ijcmas.2020.908.402 